\title{
Analisis Sanksi Pidana Terhadap Pelaku Tindak Pidana Narkotika
}

\author{
Muhammad Asyharuddin1, Baharuddin Badaru ${ }^{2}$, ${ }^{*}$ Muhammad Kamal \\ Hidjaz $^{3}$ \\ ${ }^{1}$ Mahasiswa Program Pascasarjana Universitas Muslim Indonesia \\ 2,3 Fakultas Hukum, Universitas Muslim Indonesia \\ *Email Correspondensi: muhkamal.hidjaz@umi.ac.id \\ No. Handphone Correspondensi : (+62) 813-5589-1400
}

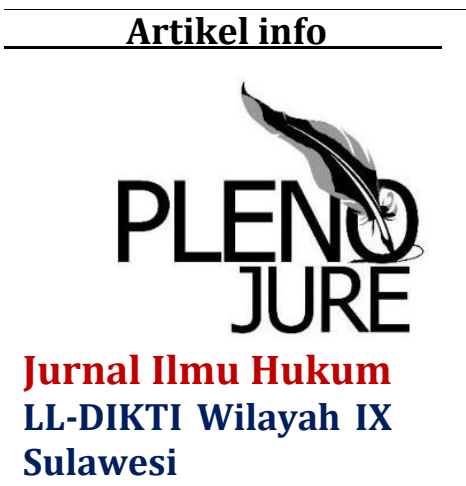

Artikel history:

Received : 07 April 2020

Revised : 28 April 2020

Accepted : 29 April 2020

\begin{abstract}
Abstrak. Penelitian ini dilakukan dengan bertujuan (1) untuk mengetahui dan memahami efektivitas pelaksanaan Sanksi pidana terhadap pelaku tindak pidana narkotika. (2) Untuk mengetahui dan memahami faktor-faktor apakah yang mempengaruhi efektivitas sanksi pidana terhadap pelaku tindak pidana narkotika. Jenis penelitian ini adalah penelitian normatif empiris dan dilakukan di Pengadilan Negeri Makassar serta respondenya adalah Hakim Pengadilan Negeri Makassar, dan Penyidik BNN Makassaar. Hasil Penelitian ini menunjukan : Evektivitas pelaksanaan Sanksi pidana terhadap pelaku tindak pidana narkotika kurang efektif diakibatkan oleh adanya penjatuhan pidana yang tidak memberikan dampak atau deterrent effect terhadap pelakunya. Faktor yang memperngaruhinya adalah lingkungan, agama, dan pekerjaan. Sebagai saran: para pembuat undang-undang hendaknya memberikan pedoman penindasan khusus yang memenuhi skala prioritas tentang narkotika sebagai pedoman pemidanaan mengenai pertimbangan hakim dalam menjatuhkan sanksi, karena KUHP belum cukup menjadi pedoman pemidanaan bagi hakim, dimana Hakim sebagai penegak hukum yang berwenang mengadili hanya mempertimbangkan faktorfaktor yang ada dilapangan pada saat persidangan.
\end{abstract}
Abstract. This research was conducted with the aim of (1) to find out and understand the effectiveness of the implementation of criminal sanctions against narcotics offenders. (2) To find out and understand what factors affect the effectiveness of criminal sanctions against narcotics offenders. This type of research is empirical normative research and is carried out in the Makassar District Court and the respondents are Makassar District Court Judges and BNN Makassaar Investigators. The results of this study indicate: The effectiveness of the implementation of criminal sanctions against narcotics offenders is less effective due to criminal convictions that have no impact or deterrent effect on the perpetrators. Factors that influence it are the environment, religion, and work. As a suggestion: lawmakers should provide specific guidelines on the oppression that meet the priority 
scale on narcotics as a guideline for judicial consideration in imposing sanctions because the Criminal Code has not been sufficiently a guideline for convicting judges, where Judges as law enforcement authorities are authorized to only consider factors-factors that exist in the field at the hearing.

\author{
Keywords: \\ narkotika; sanksi \\ pidana; pidana \\ khusus;.
}

\section{PENDAHULUAN}

Seiring dengan kemajuan yang dialami oleh masyarakat dalam berbagai bidang bertambah juga peraturan hukum. Penambahan peraturan hukum itu tidak dapat dicegah karena masyarakat berharap dengan bertambahnya peraturan tersebut, kehidupan dan keamanan bertambah baik walaupun mungkin jumlah pelanggaran terhadap peraturan-peraturan itu bertambah. Dilihat dari segi geografis, Indonesia yang berpenduduk Sekitar 200 juta jiwa lebih, dengan daratan seluas lebih kurang 1,9 Km persegi lautan (perbandingan dan lautan adalah 1:4) merupakan wilayah yang rawan bagi berkembanganya masalah penyalahgunaan narkoba. Maraknya lalulintas perdagangan narkotika dan psikotropika di Indonesia juga bermuara posisi indonesia yang terletak diantara dua benua dan dua samudra, yang mengelilingi Indonesia membuat lalu lintas perdagangan menjadi rawan. Tanah Indonesia juga subur untuk kultivas gelap tanaman ganja. ${ }^{1}$

Penyalahgunaan narkotika sudah sampai pada taraf memperhatikan, bukan hanya kuantitas penyalahgunaannya yang semakin banyak dan meluas akan tetapi penggunanya juga telah menjalar hampir ke lapisan masayarakat mulai dari pelajar, hingga pejabat negara pun terlibat dalam tindak pidana narkotika ini. Peredaran narkotika di Indonesia mempunyai kecenderungan meningkat dan yang sangat disayangkan pengguna narkotika saat ini sudah mulai dilakukan aparat pemerintahan dan penegak hukum. ${ }^{2}$

Narkoba adalah singkatan dari Narkotika, Psikotropika dan Bahan Adiktif Berbahaya lainya. Kata Narkotika pada dasarnya berasal dari Yunani "narkoun" yang berarti membuat lumpuh atau mati rasa. Disebutkan bahwa Narkotika adalah zat atau obat yang berasal dari tanaman atau bukan tanaman, baik sintetis maupun semisintetis, yang dapat menyebabkan penurunan atau perubahan, hilangnya rasa nyeri, dan dapat menimbulkan ketergantungan. ${ }^{3}$

Ada beberapa alasan mengapa bangsa Indonesia harus lebih serius dalam pemberantasan tindak kejahatan narkotika. Pemerintah Indonesia belum optimal dalam menanggulangi kasus penyalahgunaan dan peredaran gelap narkoba. Hal ini mengisyaratkan kepada kita untuk lebih peduli dan

\footnotetext{
${ }^{1}$ Lydia Harlina Martono \& Satya Joewana ,( 2005), MembantuPemulihan Pecandu Narkotika dan Keluarga, Balai Pustaka, Jakarta, hal. 1

2 Dahlan,(2017) Problematika Keadilan dalam Penerapan Pidana terhadap Penyalah Guna Narkotika,

Yogyakarta: Deepublish Yogyakarta. hal.4

${ }^{3}$ Irwan Jasa Taringan, (2017), Peran Badan Narkotika Nasional dengan Organisasi Sosial Kemasyarakatan dalam Penanganan Pelaku Penyalahgunaan Narkotika Deepublish: Yogyakarta.hal. 15
} 
memperhatikan secara lebih khusus untuk menanggulanginya. Secara yuridis, instrumen hukum yang mengaturnya baik berupa peraturan perundangundangan maupun konvensi yang sudah diratifikasi, sebenarnya sudah cukup memadai sebagai dasar pemberantasan dan penyalahgunaan peredaran gelap narkoba. Mengingat peredaran gelap narkotika sekarang ini begitu merebak dan kadang didalam lapas pun sering terjadi transaksi oleh oknum. Maka upaya menanggulanginya tidak dapat semata-mata dibebankan kepada pemerintah dan aparat penegak hukum saja, dengan memberlakukan peraturan dan penjatuhan sanksi pidana kepada para pelanggar hukum. Melainkan tugas dan tanggung jawab kita bersama.

Kehadiran upaya terpadu (integrated) dari semua pihak, seperti keluarga, sekolah, masyarakat, ulama, LSM dan pemerintah termasuk BNN diharapkan dapat menanggulangi dan meminimalisir kasus tindak pidana narkoba. Masyarakat indonesia saat ini sedang di hadapkan pada keadaan yang sangat mengkhawatirkan akibat maraknya peredaran gelap narkoba, pengguna narkoba secara ilegal ditengah kehidupan masyarakat, hal ini dikenal dengan narkotika yang memiliki definisi golongan obat yang mempengaruhi Susunan Saraf Pusat (SSP) ada yang memberikan depresi(Opium, Morphine, Heroin) dan ada pula yang diberikan stimulasi pada SSP (Cocaine). ${ }^{4}$

Bahaya penyalahgunaan tidak hanya terbatas dari diri pecandu, melainkan dapat membawa akibat yang lebih jauh lagi yaitu gangguan terhadap tata kehidupan masyarakat yang bisa berdampak malapetaka bagi bangsa, olehnya menjadi rumusan masalah yaitu: Deskripsi penyalahgunaan narkoba dewasa ini dan efektivitas sanksi pidana serta upaya pemerintah dalam penanggulangannya.

\section{METODE}

Penelitian ini menggunakan tipe penelitian Normatif empiris (Social Legal Research), yaitu selain mengkaji hukum secara teoretik dan normatif (Law in Book) juga untuk mengkaji dan mengamati proses bekerjanya hukum (Law in Action) yang relevan dengan permasalahan yang diteliti. Penelitian ini dilakukan di Pengadilan Negeri Makassar. Adapun pemilihan lokasi penelitian didasarkan pada pertimbangan bahwa melihat tugas yang diemban oleh BNN (Badan Narkotika Nasional) yang bertugas dalam mengawasi dan memeriksa tingkatan penyebaran dan penyalahgunaan narkoba atau narkotika dalam menjalankan jabatannya sangat erat kaitannya dalam mengetahui bagaimana seharusnya penduduk di kota Makassar terbebas dari narkoba atau narkotika. Sedangkan, penentuan lokasi penelitian pada kantor BNN (Badan Narkotika Nasional) karena berkaitan langsung dengan subjek yang diteliti, dimana penulis berpandangan bahwa dengan penelitian yang diadakan pada lokasi penelitian tersebut di atas akan memudahkan penulis dalam memperoleh datadata yang diperlukan dalam penulisan ini. Populasi penelitian ini adalah segenap obyek pengamatan penelitian dari populasi tersebut, ditarik sampel yang memiliki segenap populasi tersebut, ditarik sampel yang memiliki segenap populasi berdasarkan karakternya, yang terdiri: Hakim Pengadilan Negeri Makassar sebanyak 1 (satu), dan Petugas BNN Makassar 2 (dua) orang.

${ }^{4}$ Nanizar Zaman Joenoes, (2001),ARS Prescribendi Resep Yang Rasional, Airlangga University

Press,Surabaya.hal.40 


\section{HASIL DAN PEMBAHASAN}

\section{A. Penyalahgunaan Narkotika}

Ketentuan tindak Pidana di bidang psitropika diatur dalam BAB XV Pasal 111 sampai dengan Pasal 148 Undang-Undang Nomor 35 Tahun 2009. Perbuatan yang diancam dengan hukuman pidana diatur dalam pasal 111 sampai dengan pasal 147, dan seluruhnya merupakan delik kejahatan. ${ }^{5}$ Penggunaan narkotika secara legal hanya bagi kepetingankepentingan pengobatan atau tujuan ilmu pengetahuan. Menteri Kesehatan dapat memberi ijin lembaga ilmu pengetahuan dan atau lembaga pendidikan untuk membeli atau menanam, menyimpan untuk memiliki atau untuk persediaan ataupun menguasai tanaman papaver, koka dan ganja.

Berdasarkan Undang-undang Nomor 35 Tahun 2009 tentang Narkotika pada Pasal 11 Menyatakan :

1. Menteri memberi izin khusus untuk memproduksi Narkotika kepada Industri Farmasi tertentu yang telah memiliki izin sesuai dengan ketentuan peraturan perundang-undangan setelah dilakukan audit oleh Badan Pengawas Obat dan Makanan

2. Menteri melakukan pengendalian terhadap produksi Narkotika sesuai dengan rencana kebutuhan tahunan Narkotika sebagaimana dimaksud dalam pasal 9.

3. Badan Pengawas Obat dan Makanan melakukan pengawasan terhadap bahan baku, proses produksi, dan hasil akhir dari produksi Narkotika sesuai dengan rencana kebutuhan tahunan narkotika sebagaimana dimaksud dlam pasal 9 .

4. Ketentuan lebih lanjut mengenai tata cara pemberian izin dan pengadilan sebagaimana dimaksud pada ayat (1) dan ayat (2) diatur dalam pasal 9.

5. Ketentuan lebih lanjut mengenai tata cara pengawasan sebagaimana dimaksud pada ayat (3) diatur dengan Peraturan Kepala Badan Pengawas Obat dan Makanan. ${ }^{6}$

Dengan demikian narkoba dapat menjadi menghambat pembangunan nasional yang beraspek materiel-spiritual. Bahaya pemakaian narkoba sangat besar pengaruhnya terhadap negara, jika sampai terjadi pemakaian narkoba secara besar-besaran di masyarakat, maka bangsa Indonesia akan menjadi bangsa yang sakit, apabila terjadi demikian negara akan rapuh dari dalam karena ketahanan nasional merosot. $^{7}$

Pengedaran narkotika ini dilakukan tanpa pengawasan dari kepala Badan Pengawas Obat dan Makanan dan tidak dilengkapi dengan dokumen yang sah. Kegiatan ini meliputi Ekspor dan Impor, karena keterkaitan dengan suatu mata rantai peredaran narkotika, baik nasional maupun internasional. Setiap orang yang tanpa hak atau melawan hukum

\footnotetext{
${ }^{5}$ Irwan Jasa Taringan, (2007),Narkotika dan Penanggulanganya, Depublish: Yogyakarta.hal.41

${ }^{6}$ Ditama Binbangkum,(2009), Undang-undang Nomor 35 Tahun 2009

${ }^{7}$ Gatot Supramono (2004 ), Hukum Narkoba Indonesia,Jakarta: Djambatan, hal 5
} 
memproduksi, mengimpor, mengekspor, atau menyalurkan Narkotika Golongan I, dipidana dengan pidana penara paling singkat 5 (lima) tahun dan paling lama 15 (lima belas) tahun dan pidana denda paling sedikit Rp.1.000.000.000.00 (Satu,miliar rupiah) dan paling banyak Rp. 10.000.000.000.00 ( sepuluh miliar rupiah).

Jual beli Narkotika Ini pada umumnya dilatar belakangi oleh motivasi untuk mencari keuntungan materil, namun ada juga karena motivasi untuk kepuasan. Setiap orang yang tanpa hak atau melawan hukum menawarkan untuk dijual, menjual, membeli, menerima, menjadi perantara dalam jual, menjual, membeli, menerima, menjadi perantara dalam jual beli, menukar, atau menyerahkan Nartika Golongan I, dipidana dengan pidana penjara seumur hidup atau pidana penjara paling singkat 5 (lima) tahun dan paling lama 20 (dua puluh) tahun dan pidana denda paling sedikit Rp. 1.000.000.00 (satu miliar rupiah) dan paling banyak Rp.10.000.000.000.00 (sepuluh miliar rupiah).

Apabila bentuk tanaman tersebut beratnya melebihi 1 (satu) kilogram, atau melebihi 5 (lima) gram, pelaku dipidana dengan pidana mati. Pidana penjara seumur hidup atau pidana penjara paling singkat 6 (enam) tahun dan paling lama 20 (dua puluh) tahun dan pidana denda maksimum sebagaimana yang dimaksud diatas di tambah $1 / 3$ (sepertiga). Kebijakan kriminalisasi, perbuatan-perbuatan yang dinyatakan sebagai tindak pidana dalam Undang-Undang Nomor 35 tahun 2009 tentang Narkotika adalah sebagai berikut :

1. Menanam, memelihara, mempunyai dalam persediaan memiliki, menyimpan atau menguasai narkotika (dalam bentuk tanaman atau bukan tanaman) diatur dalam (pasal 111 sampai dengan pasal 112).

2. Memproduksi, mengimpor, mengekspor, atau menyalurkan narkotika golongan I (Pasal 113).

3. Menawarkan untuk dijual, menjual, membeli, menerima, menjadi perantara dalam jual beli, menukar, atau menyerahkan Narkotika golongan I (Pasal 114).

4. Membawa, mengirim, mengangkut, Narkotika golongan I (Pasal 115 ).

5. Setiap orang yang tanpa hak atau melawan hukum menggunakan Narkotika golongan I terhadap orang lain atau memberikan narkotika golongan I untuk digunakan orang lain (Pasal 116).

6. Tanpa hak atau melawan hukum memiliki, menyimpan, menguasai atau menyediakan narkotika golongan II (Pasal 117).

7. Tanpa hak atau melawan hukum memproduksi, mengimpor, mengekspor, atau menyalurkan narkotika golongan II (Pasal 118).

8. Menawarkan untuk dijual, menjual, membeli, menerima, menjadi perantara dalam jual beli, menukar, atau menyerahkan Narkotika golongan II (pasal 119).

9. Membawa, mengirim, mengangkut, atau mentransito Narkotika golongan II (Pasal 120)

10. Setiap orang yang tanpa hak atau melawan hukum menggunakan Narkotika golongan II terhadap orang lain atau memberikan Narkotika golongan II untuk digunakan orang lain (Pasal 121) 
11. Setiap orang yang melawan tanpa hak atau melawan hukum menyimpan, menguasai, atau menyediakan Narkotika golongan II (pasal 122)

12. Setiap orang yang tanpa hak atau melawan hukum memproduksi, mengimpor, mengekspor, atau menyalurkan Narkotika golongan III (pasal 123).

13. Setiap orang yang tanpa hak atau melwan hukum menawarkan untuk dijual, menjual, membeli, menerima , menjadi perantara dalam jual beli, menukar, atau menyerahkan Narkotika dalam golongan III (pasal 124).

14. Membawa, mengirim, mengangkut, atau mentransito Narkotika golongan III ( pasal 125 )

15. Setiap oarang yang tanpa hak atau melawan hukum menggunakan Narkotika golongan III terhadap orang lain atau memberikan Narkotika golongan III untuk digunakan orang lain ( pasal 126).

1. Setiap penyalah guna : pasal 127 ayat 1 ).

2. Narkotika golongan I bagi diri sendiri

3. Narkotika golongan II bagi diri sendiri

4. Narkotika golongan III bagi diri sendiri

5. Pecandu Narkotika yang belum cukup umur (pasal 55 ayat 1) yang sengaja tidak melapor (pasal 128).

6. Setiap orang tanpa hak melawan hukum : (pasal 129).

7. Memiliki, menyimpan menguasai atau menyediakan perkursor Narkotika untuk pembuaatan Narkotika

8. Memproduksi, mengimpor, mengekspor atau menyalurkan perkursor Narkotika untuk pembuatan narkotika.

9. Menawarkan untuk dijual, menjual, membeli, menerima, menjadi perantara dalam jual beli, menukar, atau menyerahkan perkursor Narkotika untuk pembuatan Narkotika.

10. Membawa, mengirim, mengangkut, atau mentranssito perkursor Narkotika untuk pembuatan Narkotika.

Salah satu masalah pokok dalam pidana yang sering menjadi perdebatan para ahli hukum adalah masalah pidana, disamping masalah pokok yang lain yaitu masalah tindak pidana dan masalah kesalahan. Ketiga masalah pokok tersebut masing-masing mempunyai persoalannya sendiri, dimana satu sama lain berkaitan erat dengan persoalan dasar manusia yakni hak-hak asasi manusia.

Narkotika merupakan zat atau obat yang sangat bermanfaat dan diperlukan untuk pengobatan penyakit tertentu, namun jika disalahgunakan atau digunakan tidak sesuai dengan standar pengobatan dapat menimbulkan akibat yang sangat merugikan bagi perseorangan atau masyarakat khususnya generasi muda. ${ }^{8}$ Dalam perspektif kebijakan pidana, penanggulangan kejahatan hakikatnya merupakan suatu usaha yang rasional dan masyarkat dalam menanggulangi kejahatan.

\footnotetext{
${ }^{8}$ Hikmawati, P. (2016). Analisis Terhadap Sanksi Pidana Bagi Pengguna Narkotika. Negara Hukum: Membangun Hukum untuk Keadilan dan Kesejahteraan, 2(2), 329-350. hal, 331
} 


\section{B. Efektivitas Sanksi Pidana Terhadap Pelaku Tindak Pidana Penyalahgunaan narkotika}

Untuk mencegah dan memberantas penyalahgunaan dan peredaran gelap narkotika yang sangat merugikan dan membahayakan kehidupan masyarakat, bangsa, maka di buatlah Peraturan Pasal 60 Undang-undang Nomor 22 Tahun 1997 tentang Narkotika, yang diperbarui di dalam Undang-undang Nomor 35 Tahun 2009 tentang Narkotika, ${ }^{9}$ perundangan tersebut diharapkan pula dapat menimbulkan efek jera kepada pelaku dengan memperhatikan sanksi yang telah ditetapkan oleh pembuat undang-undang serta memberikan kepastian.

Apabila orang mendasarkan hukum pidana pada konsepsi perlindungan masyarakat/social defence, maka tugas selanjutnya adalah mengembangkan serasional mungkin. Hasil-hasil maksimum haarus dicapai dengan biaya yang minimum bagi masyarakat dan minimum penderitaan bagi individu. Dalam tugas demikian, orang harus mengandalkan pada hasil-hasil penelitian ilmiah mengenai sebab-sebab kejahatan dan efektivitas dari bermacam-macam sanksi. ${ }^{10}$

Dipandang dari segi ekonomi sosial, kerugian masyarakat yang disebabkan kejahatan di negara-negara yang telah maju maupun di negaranegara yang sedang berkembang adalah sangat besar sekali masyarakat diperhadapkan pada suatu fenomena yang terbentang luas dan mendalam bersarang sebagai penyakit menular di dalam tubuhnya sehingga sering membahayakan kehidupan. Karena penerapan hukum yang melenceng terhadap penanganan penyalah guna narkotika menjadi tidak menunjukan progresivitas, alias jalan ditempat. ${ }^{11}$

Itulah sebabnya maka di mana-mana diseluruh dunia orang harus bertindak sesuai dengan aturan yang ada di sana, baik peraturan itu berasal dari norma-norma agama, aturan-aturan kesusilaan, kebiasaan , adat-istiadat, adat aturan dari pemerintahanya sendiri. Agar tindakan seseorang tidak merugikan kepentingan orang-orang lain, contohnya, tidak boleh mengambil harta orang lain tanpa seizin yang punya, segala perbuatan yang baik haruslah mendahulukaan tempat duduk buat wanita daripada laki-laki. Wajarlah melanggar norma-norma yang berlaku dan dijunjung tinggi suatu masyarakat atau sifatnya menyimpang dari normanorma yang berlaku mendapatkan nilai dan reaksi yang bersifat tidak disukai atau akan mendapatkan hukuman yang setimpal dengan perbuatanya, agar kelak perbuatan yang demikian tidak akan terulang lagi.

Pengguna narkotika Merupakan salah satu bentuk kejahatan dalam masyarakat. Penggunaan Narkotika Merupakan Crime Without Victim (Kejahatan tanpa korban) karena pada hakikatnya pengguna menjadikan

\footnotetext{
${ }_{9}^{9}$ Muhammad Iqbal Ratu Bangsawan (2019), Implementasi Pemusnahan Barang Bukti Narkotika.hlm.8

${ }^{10}$ Barda Nawawi Arief(2005), Bunga Rampai Kebijakan Hukum Pidana, Bandung: Citra Aditya Bakti, hlm. 35.

${ }^{11}$ Anang Iskandar,(2019) Penegakan Hukum Narkotika Jakarta :

Kompas Gramedia Bullding2019).hlm.68
} 
diri mereka sebagai korban. Kasus Narkotika di Kota Makassar lebih banyak digunakan oleh remaja antara 12 - 18 tahun. bahwa sejak lahir kedunia, masyarakat telah dibekali naluri oleh Tuhan yang senantiasa mendorongnya untuk selalu mengadakan hubungan sosial dengan sesamanya. Dengan kata lain masyarakat memiliki kekuatan tertentu yang selalu menyeretnya untuk selalu hidup berkumpul dengan manusia lainya. Ini terjadi karena manusia adalah makhluk yang memiliki banyak kekurangan serta keterbatasan.

Jadi merupakan hal yang wajar apabila manusia begitu giat ke sana kemari mencari kawan gaul. Pekerjaan ini merupakan hakikat dirinya sebagai makhluk sosial. Dengan melihat kenyataan ini, maka hidup siapapun tidak perlu merasa aneh bila remaja sebagai makhluk sosial selalu giat bergerak mencari kawan-kawan dalam pergaulanya, siapapun juga akan mereka jadikan teman dalam pergaulan asal cocok dengan dirinya, tidak pandang bulu bahkan tanpa melihat status sosial. ${ }^{12}$

Namun sayang, dari sikap pergaulan ini banyak remaja yang terjerumus atau tidak jeli dalam mencari kawan bergaulnya. Sehingga tidak jarang remaja yang tadinya tergolong kategori positif, setelah lama berkecimpung dengan kawan-kawanya yang termasuk dalam kategori negatif, lunturlah sifat-sifat positif yang tadinya melekat pada diri remaja tersebut. Banyak remaja kecanduan minuman keras, mengkonsumsi narkotika atau dalam bentuk ganja yang di isap seperti rokok, dan ini berawal dari coba-coba dan sehingga membuat masalah kecanduan bahkan menjadi tergantung.

Selain itu ada juga remaja kebiasaanya mengkonsumsi narkotika di karenakan faktor malu atau di ejek dengan teman-temanya dan dikatakan tidak moderen dan tidak gaul. Sehingga untuk menghapus kesan-kesan nista itu dari dirinya kemudian dia pun ikut-ikutan mengkonsumsinya yg berawal dari minum-minuman, ganja ekstacy dan lain-lainya, akhirnya remaja tersebut menjadi remaja yang sudah tergantung pada barang haram tersebut. 13

Berikut ini beberapa ciri perkembangan remaja yang kondusif terhadap pengguna zat psikoaktif:

1. Pada masa peralihan dari masa Kanak-kanak ke masa dewasa sering timbul perasaan tertekan, ketegangan, keresahan, kebingungan rasa tidak aman, perasaan sedih, bahkan depresi. Zat psikoaktif sering digunakan oleh remaja untuk menghilangkan perasaan tersebut. Perasaan itu memang dapat berkurang atau hilang oleh zat psikoaktif, tetapi hanya bersifat sementara.

2. Kebutuhan akan pergaulan dengan teman sebaya mendorong remaja untuk dapat diterima sepenuhnya dalam kelompoknya diterimanya seorang remaja dalam kehidupan kelompoknya merupakan suatu peristiwa yang

\footnotetext{
12 Wawancara dengan. Agus Rusianto, Hakim Pengadilan Negeri Makassar Pada Tanggal 12 Februari 2020

${ }^{13}$ Wawancara dengan. Wawan, Petugas Pengadilan Negeri Makassar Pada Tanggal 12 Februari 2020
} 
membanggakan dan meningkatkan atau mempermudah interaksi remaja dengan kelompok sebayanya (vehicle of social interaction).

3. Gangguan mental dan perilaku akibat penggunaan zat psikoaktif dapat dipandang sebagai suatu penyimpangan perilaku, suatu perilaku menentang nilai-nilai yang dianut oleh masyarakat orang dewasa (adult society). Proses perkembangan jiwa remaja normal menuntut separasi dari otoritas orangtua dan mengembangkan otoritas dan identitas dirinya sendiri. Pada saat itu terdapat dorongan untuk memberontak atau melawan apa saja yang berbau 14

Bagi kita kedewasaan memang selalu harus berarti lengkap, artinya baik secara biologis, rohani maupun intelektual. Seorang dewasa pada suatu saat akan melakukan hal-hal yang tidak pada tempatnya, malah bukan saat dikatakan seperti remaja, melainkan disebut sebagai keankkanakan, jadi jelaslah bahwa siapa yang dikatakan dewasa, itu artinya sudah memenuhi persyaratan atau melewati batasan tertentu. Sayang, remaja masa kini justru jadi populer karena seringnya dihubungkan dengan kenakalanya, lebih sempit dengan penyalahgunaan narkotika.

Meskipun sesungguhnya kurang adil kalau kita lemparkan kesalahan-kesalahan ini hanya kepadanya, karena sesungguhnya yang berdiri di belakang mereka para pengedar, pedagang piskotropika atau narkotika itu sendiri baik dengan dalih memburu keuntugan atau bukan memang secara politis bermaksud subversif. Semua jenis Pisikotropika ini, sesungguhnya mempunyai akibat ataupun pengaruh yang serupa pada tubuh. Ia berpengaruh karena bergerak pada seluruh sistem tubuh. Akan tetapi yang paling baku adalah pada sistem syaraf.

Narkotika melemahkan pusat sistem syaraf, terutama pada otak dan sumsum tulang belakang. Ia menyebabkan kurangnya segala gearakan tubuh. Ia melemahkan daya tahan tubuh. Yaitu rangsangan dari rasa khawatir dan tak luput pula mendatangkan rasa ngantuk dengan klimaks tidur. Celakanya, dengan dosis yang kecil pun seorang dapat tergelincir ke dalamnya , dan hilangnya kesadaran. Angka yang telah menunjukan begitu banyaknya kematian sebgai akibat dari pemakaian narkotika yang berlebihan dan mengakibatkan kecanduan. Penggunaan narkotika akan menghambat seluruh pernafasan, sehingga yang bersangkutan tidak sempat mendapatkan oksigen yang amat diperlukan. Sementara akibat lainya, organ tubuh mengunci termasuk diantaranya kian mengerutnya biji mata, asal mula pusing-pusing, mau muntah, gatal-gatal dan kian melemahnya tekanan darah.

Kenyataanya banyak membuktikan bahwa tidak sediikit pecandu narkotika yang meninggal dunia setelah menggunakan secara bebas, tidak jarang seseorang yang baru berhenti menggunakan beberapa waktu, kemudian kembali menggunakanya dengan takaran yang lebih tinggi

${ }^{14}$ Joewana, Satya. (2004). Ganguan Mental dan Prilaku Akibat Penggunaan Zat Psikoaktif. EGC: Jakarta. Hal.286 
dosisinya. Pemakaian yang terus-menerus mengakibatkan datangnya ketergantungan fisik. Dalam hal ini sel-sel dan semua sistem syaraf tergantung pada narkotika untuk kenormalanya. Adapun sisanya membentuk kerusakan dalam fungsi syaraf yang pada akhirnya berpengaruh terhadap tudbuh. Inilah yang disebut sindrom, yang tidak lain artinya adalah mengandung kembali pengaru piskotropika.

Pada orang-orang yang tergantung pada jenis-jenis obat yang dilarang seperti narkotika ini berlangsung sekitar 6 sampai 12 jam setelah takaran obat berakhir. Lalu kesakitan pun mencapai dua hari. Ujung dari kesakitan ini ditandai dengan rasa panas, mata berair, kejang-kejang, mula panas badan berikut tekanan darah tinggi , dan gangguan-gangguan lainya lagi. Parah ahli telah membuktikan pula penngaruh Narkotika yang mengakibatkan ketergantungan. Kemudian mereka berfikir, untuk memecahkan bagaimana caranya memberikaan penjelasan bagi orangorang yang telah telanjur kecanduan itu. Namun bagaimanapun mereka berkesimpulan bahwa faktor-faktor lain disamping yang krisis ini, merupakan suatu hal yang harus diperhitungkan.

Dalam kehidpan saat ini, masalah narkotika atau piskotropika merupakan suatu masalah yang patut untuk memerlukan perhatian lebih dari semua pihak. Ada berbagai macam Naza, Naza yang disalahgunakaan adalah berupa ganja, alkohol, morfin, heroin. Kokain dan narkotika lainya, sedangkan yang dimaksudkan dengan zat jenis piskotropika disini adalah :

a. Golongan Psikodesleptika, yaitu lisegik, dietilamina/LSD meskalina, psilosibina dan zat lain yang khasiatnya serupa.

b. Golongan Stimulansia, yaitu amfetamina dan turunanya dan zat lain yang khasiatnya serupa

c. Golongan Hipnotika, yaitu barbiturat dan persenyawaanya serta lain khasiatnya

d. Golongan Ansiolitika dan zat lain yang khasiatnya serupa

Dari sudut penyalahgunaan narkotika dapat mengakibatkan gangguan mental organik akibat narkotika atau disebut juga sindrom otak organik, yang disebabkan oleh efek langsung dari narkotika tersebut terhadap susunan syaraf pusat/otak. Akibat lain adalah yang disebut sebagai gangguan pengguna naza yang menyoroti perubahan perilaku yang berkaitan dengan pengguna naza yang mempengaruhi susunan pusat syaraf. Penyalahgunaan narkotika ialah pemaikaian diluar indikasi medik, tapi tanpa petunjuk/resep dokter, pemakaian sendiri secara relatif teratur atau berkata sekurang-kurangnya selama satu bulan. Pemakaian bersifat patologik dan menimbulkan perusakan dalam fungsi sosial, dan sekolah.

Ketergantungan narkotika adalah penyalahgunaan narkotika yang disertai dengan adanya toleransi dan gejala putus asa WHO (1969) memberikan batasan tentang obat (drug) setiap zat (bahan/substansi) yang jika masuk kedalam organisme hidup akan mengadakan perubahan pada satu atau lebih fungsi-fungsi organisme tersebut. Narkotika mempunyai efek seperti itu, khususnya dalam fungsi berfikir, perasaan dan 
perilaku orang yang memakainya. ${ }^{15}$ Adapun jumlah pelaku tindak pidaana Narkotika di Kota Makassar pertahun dan sesuai data dari Pengadilan Negeri Makassar adalah:

\section{Jumlah Terpidana Kasus Narkotika di pada Pengadilan Negeri Makassar Tahun 2017 - 2019}

\begin{tabular}{cc}
\hline \multirow{2}{*}{ Tahun } & Jumlah Pelaku \\
\hline & \\
$\mathbf{2 0 1 7}$ & 851 orang \\
$\mathbf{2 0 1 8}$ & 829 orang \\
$\mathbf{2 0 1 9}$ & 844 orang \\
\hline Jumlah & 3524 orang \\
\hline Sumber : Pengadilan & Negeri Makassar , Tahun 2020
\end{tabular}

Berdasarkan tabel di atas, jumlah terpidana pada tindak pidana narkotika adalah sejumlah 3524 orang. Dilihat dari sudut penanganan perkara dalam perkara tindak pidana narkotika, Pengadilan Negeri Makassar selama kurun waktu 3 tahun (2017-2019), dari jumlah terdakwa sebanyak 3524 orang, tampak bahwa dari terdakwa narkotika yang diputus sebagaian besar dijatuhi 4 empat tahun ke atas, dilihat dari Tabel di atas terlihat bahwa dalam kurun waktu 3 tahun, jumlah pelaku tindak pidana narkotika di Makassar, berdasarkan jenis kelamin, secara umum pelaku kejahatanya banyak dilakukan oleh pria. Berdasarkan data ini maka selama 5 tahun 3 tahun (207-2019) pelaku tindak pidana narkotika dilakukan oleh para pelaku yang masih berusia muda yaitu berumur 15 tahun sampai 18 tahun. Dengan demikian dapat dinyatakan bahwa pelaku tindak narkotika secara umum, berdasarkan faktor usia maka pelaku yang berusia 20 tahun sampai 30 tahun atau lebih, telah mendominasi tindak pidana tersebut, selama kurun waktu 3 tahun.

Undang-Undang Nomor 35 Tahun 2009 tentang Narkotika tersebut dibutuhkan sosialisasi secara komperhensif dengan di dukung peraturan pemerintah secara lengkap. ${ }^{16}$ Pengertian Penyalahgunaan Narkotika Pasal 1 ayat (15) Undang-Undang Nomor 35 Tahun 2009 tentang Narkotika tidak memberikan penjelasan yang jelas mengenai istilah penyalahgunaan tersebut. Hanya istilah penyalahguna yaitu orang yang menggunakan narkotika tanpa hak atau melawan hukum. Penyalahgunaan narkotika dan penyalahgunaan obat (drug abuse) dapat pula diartikan

15 Wawancara dengan .Ahmad Budiarto. Penyidik BNN Makassar PadaTanggal 18 Februari 2020

${ }^{16}$ Wawancara dengan Agus Rusianto, Hakim Pengadilan Negeri Makassar 2020 Pada Tanggal 12 Februari 2020 
mempergunakan obat atau narkotika bukan untuk tujuan pengobatan, padahal fungsi obat narkotika adalah untuk membantu penyembuhan dan sebagai obat terapi. Apabila orang yang tidak sakit 37 mempergunakan narkotika, maka ia akan merasakan segala hal yang berbau abnormal.

Penerapan sanksi pidana terhadap pelaku tindak pidana penyalahgunaan Narkotika yang belum optimal terlihat pada putusan pengadilan yang diperoleh dalam penelitian. Dalamm putusan Pengadilan Negeri Makssar No 1390/Pid.Sus/2019/PN.Mks Seorang Pelaku tindak pidana Penyalahguna Narkotika yang memiliki dan menguasai Narkotika, Menurut pasal 112 ayat (1) Undang-undang No 35 Tahun 2009 Tentang Narkotika Menjatuhkan pidana 4 tahun dan 6 bulam dan denda sebesar RP. 800.000.00 (delapan ratus juta rupiah)

\section{Upaya pemerintah Meminimalisir Penyalahgunaan Narkotika dan Partisipasi Masyarakat.}

Upaya pemerintah dalam meminimalisir penyalahgunaan narkotika dalam penelitian ini di kelompokan dua upaya yaitu melalui jalur preventif dan jalur represif

\section{a. Upaya Preentif}

Upaya preventif penyalahgunaan narkotika di kota Makassar dilakukan dengan beberapa cara antara lain melakukan kegiatan rutin para petugas BNN Makassar yaitu kegiatan sosialisasi atau penyuluhan di daerah-daerah dan sekolah-sekolah dan memberikan stiker-stiker yang bertulisan katakan tidak untuk narkoba. Upaya-upaya tersebut dilaksanakan secara terpadu dengan instansi-instansi terkait seperti kejaksaan, pengadilan, rumah sakit, pendidikan nasional dan pemerintah kota termasuk pihak Pelindo dan Bea Cukai yang menguasai peredaran Narkotika di pelabuhan-pelabuhan yang ada di Kota Makassar.

Upaya-upaya dimaksud bahkan setiap tahun pelaksanaanya semakin meningkat baik dari segi kualitas maupun secara kuantitas dengan menerunkan petugas dan penyuluh yang menguasai materi dibidang Pisikotropika. ${ }^{17}$ Sesuai dengan hasil penelitian tentang tindakan preventif dalam meminimalisir penyalahgunaan Narkotika, maka aparat penegak hukum secara terkait yaitu Kepolisian, Kejaksaan, Kehakiman, Pelindo dan Petugas Bea Cukai melakukan beberapa upaya.

Sesuai dengan hasil penelitian tentang tindakan preventif dalam meminimalisir penyalahgunaan Narkotika, maka aparat penegak hukum secara terkait yaitu Kepolisian, Kejaksaan, Kehakiman, Pelindo dan Petugas Bea Cukai melakukan beberapa upaya yang meliputi :

a) Pemerintah Kota Makassar melakukan penyuluhan dengan melibatkan elemen pemerintah secara terkait yang bertugas

${ }^{17}$ Wawancara dengan Ahmad Budiarto Penyidik BNN (Badan Narkotika Nasional Makassar) Pada Tnggal 
untuk menanggulangi Narkotika dan bekera sama dengan para pihak sekolah-sekolah dan kampus kampus yang ada di Kota Makasar

b) Pengawasan secara terpadu pada pintu-pintu masuk Kota Makassar seperti Pelabuhan laut dan udara dengan harapan dapat memutuskan mata rantai peredaran gelap Narkotika dan barang berbahaya lainya.

\section{b. Upaya Represif}

Upaya menimalisir secara represif berdasarkan hasil penelitian dapat diuraikan bahwa penanganan kasus Penyalahgunaan Narkotika, dari hasil wawancara peneliti dengan Hakim Pengadilan Negeri makassar menjelaskan bahwa para pelaku pada umunya sangat tertutup dan saling melindungi pada saat proses pemriksaan sehingga sulit mengungkap ringan atau pelaku lain yang turut terlibat dalam kasus yang sedang di kembangkan oleh kepolisian.

Mengenai hukuman yang dijatuhkan terhadap pelaku Penyalahgunaan Narkotika sesuai dengan Undang-undang Nomor 35 tahun 2009 tentang narkotika pasal 112 ayat (1) bahwa rata-rata hukuman yang dijatuhkan kurang dari atau minimal pidana 4 tahun dan 6 bulan serta denda sebesar Rp.800.000.000,-(Delapan ratus juta rupiah) Pada tahapan pembinaan narapidana atau pelaku sebagai bagian dari upaya represif, para pelaku penyalahgunaan narkotika membutuhkan pembinaan khusus untuk mencegah adanya upaya narapidana memperoleh narkotika dan zat adiktif lainya meskipun berada dalam tahanan, seperti banyak terjadi di Lembaga Pemasyarakatan kota-kota besar di indonesia.

\section{SIMPULAN DAN SARAN}

Efektivitas Sanksi terhadap pelaku tindak pidana penyalahgunaan narkotika menurut undang - undang No 35 tahun 2009 tentang Narkotika, Dalam kasuskasus terakhir ini telah banyak bandar- bandar dan pengedar narkoba tertangkap dan menangkap sanksi berat, namun pelaku yang lain sepertinya tidak mengacuhkan bahkan lebih cenderung untuk memperluas daerah operasinya. Penegakan hukum terhadap kejahatan di Indonesia, khususnya dalam hal pemidanaan, seharusnya merujuk pada pendekatan norma hukum yang bersifat membina penjahat dengan cara melakukan pembinaan di lembaga permasyarakatan, dengan demikian dapat memperbaiki terpidana di lembaga permasyarakatan tersebut. Faktor-faktor terjadinya penyalahgunaan Narkotka di Kota Makassar adalah Faktor internal yang meliputi adanya rasa ingin tahu. Kondisi ekonomi, keadaan keluarga/rumah tangga dan ketaatan beragama, sedangkan faktor eksternal meliputi buruknya lingkungan pergaulan dan adanya kesempatan untuk memperoleh Narkotika.

Artikel ini melahirkan beberapa saran diantaranya: Para pembuat Undangundang hendaknya memberikan pedoman penindasan khusus yang memenuhi skala prioritas tentang narkotika sebagai pedoman pemidanaan mengenai pertimbangan hakim dalam menjatuhkan sanksi pidana kepada terdakwa, karena KUHP belum cukup menjadi pedoman pemidanaan bagi hakim, di mana 
hakim sebagai penegakan hukum yang ada dilapangan pada saat persidangan. Oleh sebab itu diperlukan suatu pedoman khusus pemidanaan yang dapat membuat putusan hakim menjadi lebih obyektif. Bagi masyarakat seharusnya sadar akan peraturan yang telah diundangkan pemerintah, sehingga penyalahgunaan narkotika di lingkungan masyarakat dapat dihindari dan diminimalisir. Lingkungan masyarakat atau pergaulan. Masyarakat atau pergaulan sebagai unit lingkungan yang lebih luas, setelah lingkungan rumah tangga atau keluarga merupakan faktor eksternal yang mempunyai pengaruh yang cukup besar terhadap karakter dan tingkah laku seseorang sehingga gampang untuk tertarik dalam penyalahgunaan narkotika tersebut

\section{DAFTAR RUJUKAN}

Anang Iskandar. (2019), Penegakan Hukum Narkotika, Jakarta: Kompas Gramedia Bulding

Barda Nawawi Arief. (2005), Bunga Rampai Kebijakan Hukum Pidana, Bandung: Citra Aditya Bakti

Dahlan. (2017) Problematika Keadilan dalam Penerapan Pidana terhadap Penyalah Guna Narkotika, Yogyakarta: Deepublish Yogyakarta

Gatot Supramono (2004 ), Hukum Narkoba Indonesia, Jakarta: Djambatan

Hikmawati, P. (2016). Analisis Terhadap Sanksi Pidana Bagi Pengguna Narkotika. Negara Hukum: Membangun Hukum untuk Keadilan dan Kesejahteraan, 2(2), 329-350.

Irwan Jasa Taringan, (2017),Narkotika dan Penanggulanganya, Depublish: Yogyakarta

(2017), Peran Badan Narkotika Nasional dengan Organisasi Sosial Kemasyarakatan dalam penanganan Pelaku Penyalahgunaan Narkotika Deepublish: Yogyakarta

Hapsari, I. P. (2019). Efektivitas Penerapan Pidana Mati Terhadap Tindak Pidana Narkotika Di Indonesia. Jurnal Justiciabelen, 1(2), 241-251.

Joewana, Satya. (2004). Ganguan Mental dan Prilaku Akibat Penggunaan Zat Psikoaktif, EGC: Jakarta

Lydia Harlina Martono \& Satya Joewana ,(2005), MembantuPemulihan Pecandu Narkotika dan Keluarga, BalaiPustaka: Jakarta

Muhammad Iqbal Ratu Bangsawan (2019), Implementasi Pemusnahan Barang Bukti Narkotika.

Nanizar Zaman Joenoes, (2001),ARS Prescribendi Resep Yang Rasional, Airlangga University Press : Surabaya

Undang-undang Republik Indonesia Nomor 35 Tahun 2009 tentang Narkotika 